\title{
PENGARUH PENAMBAHAN SERAT BAMBU PADA PEMBUATAN BATA BETON DALAM KAITANNYA DENGAN KUAT TEKAN SNI 03-0349-1989
}

\author{
Dian Nopiyanti, Erna Septiandini, Rosmawita S
}

\begin{abstract}
Abstrak
Penelitian ini bertujuan untuk mengetahui perbedaan kuat tekan bata beton yang menggunakan bahan tambahan serat bambu dengan persentase yang berbeda. Penelitian ini juga bertujuan untuk mengetahui kuat tekan optimal bata beton yang menggunakan campuran serat bambu dengan kuat tekan beton SNI 03-0349-1989 mutu kelas IV.

Prosedur penelitian dilaksanakan menurut SNI 03-0349-1989 dan dilakukan di Laboratorium Bahan Bangunan Jurusan Teknik Sipil Universitas Negeri Jakarta, sedangkan benda ujinya dibuat di pabrik bata beton yang berlokasi di Jl. Kalimalang Bekasi.

Metode penelitian menggunakan metode eksperimen dengan tiga perlakuan. Populasi benda uji seluruhnya berjumlah 45 buah dengan perlakuan yang berbeda dengan bata beton standar, masing-masing perlakuan 15 buah benda uji. Sampel diambil secara acak dari seluruh benda uji yang disyaratkan dalam SNI sebanyak 10 buah dengan perincian 5 buah untuk pengujian penyerapan air dan 5 buah untuk pengujian kuat tekan.

Hasil penelitian menggunakan hipotesis statistik yaitu : 1) uji analisa variansi (ANAVA) satu jalur dengan $\alpha=0,01$, kemudian didapat $F_{\text {indeks }}=572,536$ dan tabel $=6,36$. Karena $F_{\text {indeks }}>F_{\text {tabel }}$ atau $572,536>6,36$ sehingga Ho ditolak. 2) Uji T dua rata-rata satu pihak dengan $\alpha=0,01$ kemudian dari analisa didapat $t_{\text {indeks }}=29,114$ dan $t_{\text {tabel }}=3,797$. Karena $t_{\text {indeks }}<t_{\text {tabel }}$ atau 29,114 $<3,797$ maka tolak $\mathrm{Ho}$.

Kesimpulan yang didapat dari penelitian adalah : 1) Serat bambu dapat digunakan sebagai bahan tambahan adonan bata beton untuk memperoleh hasil kuat tekan bata beton yang optimal adalah dengan persentase sebesar 3\% dari berat semen. 2) Nilai kuat tekan bata beton yang menggunakan tambahan serat bambu sebesar 0\%, 1\% dan 3\% memiliki perbedaan yang signifikan, dan memenuhi bata beton normal menurut SNI mutu kelas IV dengan nilai kuat tekannya $20 \mathrm{~kg} / \mathrm{cm}^{2}$.
\end{abstract}

Kata kunci : Serat bambu, bata beton dan kuat tekan

\section{PENDAHULUAN}

Laju pertambahan penduduk yang begitu pesat menyebabkan meningkatnya keperluan manusia dalam berbagai hal, khususnya di bidang fisik seperti pembangunan gedung perkantoran, sarana umum, sekolahan, perumahan, dan lain sebagainya baik yang dilakukan pemerintah maupun oleh swasta. Sudah tentu kebutuhan akan bahan

Dian Nopiyanti

Alumnus Jurusan Teknik Sipil

Fakultas Teknik

Universitas Negeri Jakarta, 13220
Erna Septiandini, Ir. MT

Staf Pengajar Jurusan Teknik Sipil Fakultas Teknik

Universitas Negeri Jakarta, 13220
Rosmawita S, Dra., MPd.

Staf Pengajar Jurusan Teknik Sipil Fakultas Teknik Universitas Negeri Jakarta, 13220 
bangunan akan meningkat pula guna memenuhi permintaan dari konsumen, sehingga banyak bermunculan industri yang membuat berbagai jenis bahan bangunan salah satu bahan bangunan yang dimaksud adalah bata beton yang pada umumnya digunakan untuk pasangan dinding.

Pemakaian bata beton sebagai bahan bangunan mempunyai banyak kelebihan seperti: mudah dibentuk sesuai kebutuhan, perawatan yang murah, dapat memanfaatkan bahan-bahan lokal serta kokoh. Bata beton untuk pasangan dinding ialah suatu unsur bahan bangunan yang dibuat dari campuran bahan Perekat hidrolis (semen Portland) dan agregat, ditambah air, dengan atau tanpa bahan tambahan lainnya yang tidak merugikan sifat bata beton itu.

Indonesia merupakan negara yang banyak ditumbuhi oleh tanaman bambu karena bambu merupakan salah satu hasil hutan yang dapat digunakan untuk berbagai keperluan. Selain itu bambu merupakan tanaman rakyat yang juga termasuk tanaman yang serba guna. Dalam bentuk belahan dapat dibuat sebagai bahan konstruksi rumah, jembatan, saluran air, dan sebagainya. Dalam bentuk dibelah dapat dibuat dinding, plafon rumah, barang kerajinan tangan, dan lain-lain.

Perkembangan teknologi yang begitu pesat di berbagai disiplin ilmu antara lain ilmu bahan bangunan, baik dari segi kualitas maupun kuantitas. Untuk menunjang kebutuhan komponen bangunan bagi perumahan maka penggunaan serat bambu yang berasal dari kerajinan tangan yang dibuat oleh industri kecil berupa sayatan yang halus dan tipis untuk dijadikan bahan tambahan pada pembuatan bata beton adalah merupakan suatu alternatif sebagai penyediaan bahan bangunan yang perlu dipikirkan.

Menurut penelitian David Widianto mengenai sifat mekanik beton dengan fiber bambu untuk mutu beton $\mathrm{k} 225$ penelitiannya menyatakan bahwa :

1. Penambahan serat bambu sebesar $1 \%$ dari berat semen menghasilkan kuat tekan sebesar $237,28 \mathrm{~kg} / \mathrm{cm}^{2}$

2. Penambahan serat bambu sebesar $3 \%$ dari berat semen menghasilkan kuat tekan sebesar $263,33 \mathrm{~kg} / \mathrm{cm}^{2}$ 
3. Penambahan serat bambu sebesar $5 \%$ dari berat semen menghasilkan kuat tekan sebesar $219,25 \mathrm{~kg} / \mathrm{cm}^{2}$

Dalam penelitian ini perlu adanya pembatasan masalah yang akan dibahas yaitu hanya pada penggunaan serat bambu dengan persentase yang berbeda yaitu $0 \%, 1 \%$ dan $3 \%$ terhadap berat semen sebagai bahan campuran bata beton terhadap kuat tekan bata beton.

Variabel yang digunakan dalam penelitian ini adalah sebagai berikut:

1. Variabel terikat

Variabel terikat dalam penelitian ini adalah kuat tekan bata beton

2. Variabel bebas

Variabel bebasnya adalah bata beton yang diberi tambahan serat bambu

\section{METODA}

Metode penelitian yang digunakan dalam penelitian ini adalah studi eksperimen di laboratorium dengan benda uji bata beton yang diberikan penambahan serat bambu.

Penelitian ini menggunakan dua kelompok benda uji, yaitu kelompok benda uji bata beton yang diberikan perlakuan dengan variasi campuran serat bambu sebagai kelompok uji (A1) dan kelompok kontrol kuat tekan bata beton tanpa penambahan serat bambu sebagai kelompok pembanding (A2).

Populasi dalam penelitian ini adalah bata beton berlubang dengan ukuran panjang $39 \mathrm{~cm}$, lebar $19 \mathrm{~cm}$ dan tebal $10 \mathrm{~cm}$ yang menggunakan bahan tambah berupa serat bambu yang berukuran panjang $\pm 1 \mathrm{~cm}$ dan ditambahkan sebesar $1 \%$ dan $3 \%$ terhadap berat semen, dan serat bambu yang dipakai adalah serat yang berasal dari bambu apus atau bambu tali (gigantochloa apus) karena memiliki sifat serat yang panjang, halus dan lentur. Serat bambu yang dipakai berumur \pm 3 tahun yang ditandai dengan adanya akar-akar kecil yang keluar dari nodia. Populasi terjangkau adalah benda uji bata beton dengan masing-masing kelompok berjumlah 15 buah sehingga berjumlah 45 buah benda uji. 
Sampel dalam penelitian ini adalah 10 buah untuk setiap perlakuan, masingmasing 5 buah untuk pengujian kuat tekan dan 5 buah untuk pengujian penyerapan air, sehingga benda uji keseluruhan berjumlah 30 dari 3 perlakuan.

Instrumen penelitian yang digunakan adalah seperangkat alat pengujian pasir, alat uji kuat tekan dan penyerapan air yang telah dilengkapi dengan daftar isian.

Prosedur penelitian di laboratorium adalah sebagai berikut:

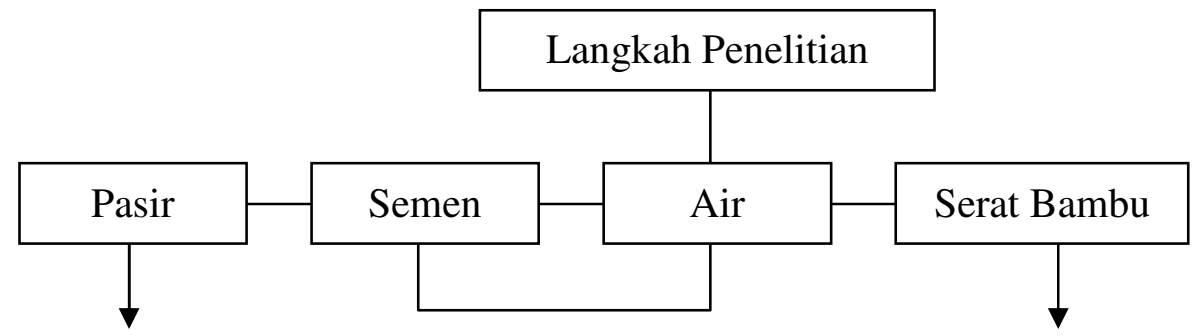

Pengujian bahan

1. Kadar air pasir

2. Kadar organis

3. Kadar lumpur

4. Butiran lolos ayakan No. 200

5. Berat isi agregat

6. Berat jenis dan penyerapan air

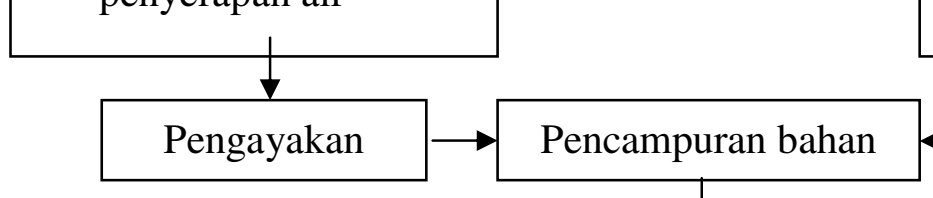

1. Perendaman selama 24 jam

2. pemeriksaan penyerapan air

3. uji panjang berkas serat batang

4. uji kehalusan serat batang
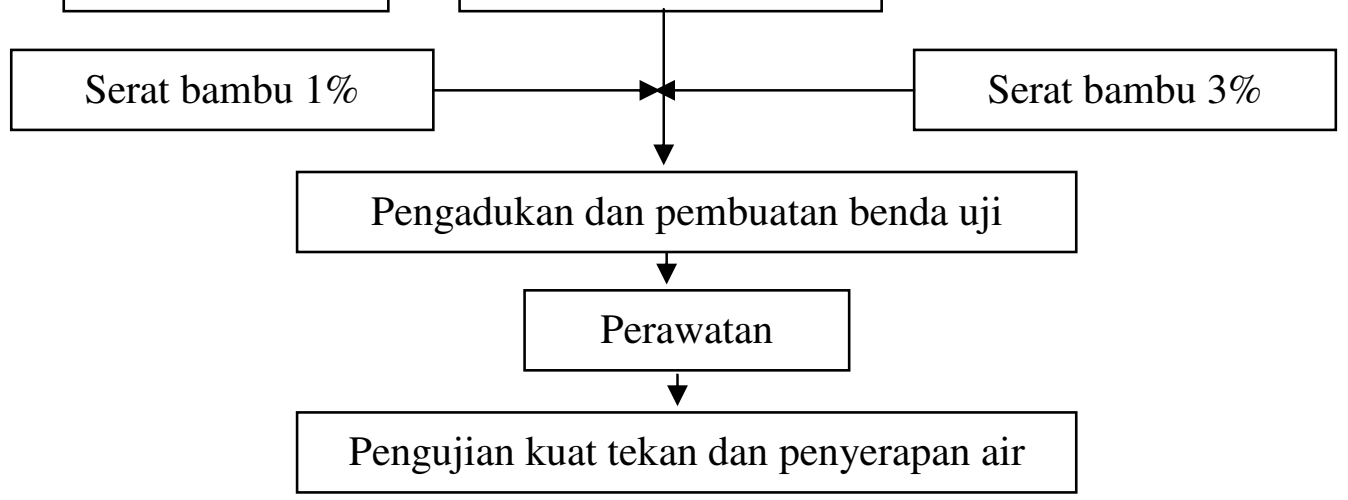

Data tentang nilai kuat tekan bata beton diambil dari hasil pengujian kuat tekan (crushing test) sedangkan data mengenai prosentase penyerapan air diperoleh dari pengujian penyerapan air. 
Teknik analisis Data yang digunakan untuk menguji hipotesis adalah uji Analisis Variasi (ANAVA) satu arah serta uji t dua rata-rata satu ihak. Sebelum menguji ANAVA dilakukan terlebih dahulu uji normalitas dan uji homogenitas.

Hipotesis statistik dalam penelitian ini yaitu :

1. Hipotesis pertama

Ho : $\mu \mathrm{A}=\mu \mathrm{B}=\mu \mathrm{C}$

Artinya tidak terdapat perbedaan yang signifikan terhadap nilai kuat tekan bata beton akibat penambahan serat bambu dengan presentase $0 \%, 1 \%$ dan $3 \%$ dari berat semen.

H1 : paling sedikit satu tanda sama dengan tidak berlaku. Artinya terdapat perbedaan yang signifikan terhadap nilai kuat tekan bata beton akibat penambahan serat bambu dengan prosentase $0 \%, 1 \%$ dan $3 \%$ dari berat semen.

Keterangan :

$\mu \mathrm{A}=$ Nilai rata-rata kuat tekan bata beton tanpa penambahan serat bambu

$\mu \mathrm{B}=$ Nilai rata-rata kuat tekan bata beton dengan penambahan serat bambu $1 \%$ dari berat semen.

$\mu \mathrm{C}=$ Nilai rata-rata kuat tekan bata beton dengan penambahan serat bambu $3 \%$ dari berat semen.

2. Hipotesis kedua

$\mathrm{Ho}=\mu_{1}=\mu_{2}$

Artinya : nilai rata-rata kuat tekan bata beton optimum yang menggunakan bahan tambahan serat bambu terhadap berat semennya dengan nilai rata-rata kuat tekan bata beton normal menurut SNI 03-0349-1989 untuk kelas IV adalah sama.

$\mathrm{H} 1: \mu_{1}>\mu_{2}$

Artinya : nilai rata-rata kuat tekan optimum yang menggunakan bahan tambahan serat bambu terhadap berat semennya lebih tinggi daripada nilai rata-rata kuat tekan bata beton normal menurut SNI untuk kelas IV. 


\section{HASIL DAN PEMBAHASAN}

\section{Kuat Tekan}

Semakin banyak penambahan serat bambu pada campuran bata beton semakin besar kuat tekan bata beton yang dihasilkan. Didapat nilai rata-rata kuat tekan bata beton dengan penambahan serat bambu sebesar $3 \%$ dari berat semen adalah yang tertinggi yaitu sebesar $25,069 \mathrm{~kg} / \mathrm{cm}^{2}$, sedangkan bata beton yang menggunakan tambahan serat bambu sebesar $1 \%$ dari berat semennya menghasilkan kuat tekan yang lebih rendah dari bata beton jenis A2 yaitu sebesar $22,012 \mathrm{~kg} / \mathrm{cm}^{2}$. Dari kedua kelompok telah didapat, kuat tekannya masih lebih besar dibandingkan dengan bata beton biasa, sehingga kedua jenis bata beton tersebut baik untuk digunakan sebagai bahan penambah dan baik dalam hal kuat tekan.

Dari hasil pengujian dapat dilihat pula adanya perbedaan dalam hal nilai rata-rata kuat tekan bata beton dari kedua kelompok sampel penelitian yang telah dibuktikan secara statistik. Untuk hasil uji rata-rata uji satu pihak dari nilai optimum kuat tekan bata beton yang menggunakan serat bambu sebagai bahan penambah sebesar $3 \%$ dari berat semen terdapat perbedaan yang signifikan dengan nilai kuat tekan bata beton minimum bata beton Standar Nasional Indonesia, dan didapat nilai optimum kuat tekan bata beton yang menggunakan serat bambu sebagai bahan penambah lebih besar 5,051 dari nilai kuat tekan minimum bata beton standar SNI 03-0349-1989 pada taraf signifikan 0,01.

Selain itu pada penambahan serat bambu sebesar $1 \%$ dari berat semen menghasilkan kuat tekan yang lebih besar dari kuat tekan bata beton standar dan untuk uji statistiknya terdapat perbedaan yang signifikan dari bata beton normal. Hal ini berarti kuat tekannya berbeda dengan kuat tekan bata beton standar dan hal ini disebabkan karena persentase serat bambunya mempengaruhi keadaan bata beton. 


\section{Penyerapan Air}

Dari pengujian penyerapan air yang dilakukan menghasilkan semakin besar serat bambu yang ditambahkan akan semakin besar pula persentase penyerapan airnya. Dilihat dari hasil rata-rata dari beberapa penelitian yang dilakukan, penambahan serat bambu terhadap berat semen dalam komposisi cukup berpengaruh terhadap penyerapan air bata beton sehingga hasilnya kurang baik dibanding bata beton standar.

\section{Bobot bata beton}

Penggunaan serat bambu sebagai bahan penambah berpengaruh pada bobot bata beton yang dihasilkan Semakin banyak serat bambu yang ditambahkan dalam komposisi adukan semakin ringan pula bobot bata beton yang dihasilkan sehingga akan mengurangi jumlah pemakaian adukan bata beton agar lebih ekonomis.

\section{Tampak Permukaan}

Pada pengujian syarat tampak permukaan, terlihat semakin tinggi persentase serat bambu yang ditambahkan maka permukaan bata beton yang dihasilkan semakin kasar.

\section{KESIMPULAN}

Berdasarkan hasil penelitian maka dapat disimpulkan sebagai berikut:

1. Serat bambu masih dapat untuk digunakan sebagai bahan tambahan adonan bata beton dan untuk memperoleh hasil kuat tekan bata beton optimum adalah dengan menggunakan persentase sebesar $3 \%$ dari berat semennya.

2. Nilai kuat tekan bata beton yang menggunakan tambahan serat bambu sebesar $0 \%$, $1 \%$ dan $3 \%$ terdapat perbedaan yang signifikan, dan memenuhi bata beton standar menurut SNI 03-0349-1989 mutu kelas IV dengan nilai kuat tekan bata betonnya adalah $20 \mathrm{~kg} / \mathrm{cm}^{2}$.

3. Hal lain yang dapat diperlihatkan dalam penelitian ini adalah pada bata beton yang menggunakan bahan tambahan serat bambu, setelah beban maksimum keruntuhan atau patahan terjadi secara perlahan dan tak terjadi patahan langsung atau terpisah. 
Hal ini karena serat bambu pada bata beton tidak seluruhnya ikut putus, sehingga masih dapat menahan antar bagian satu dengan yang lainnya.

4. Semakin besar penambahan serat bambu pada adukan bata beton maka semakin besar penyerapan air yang terjadi.

5. Semakin besar penambahan serat bambu pada bata beton maka semakin ringan bobot bata beton yang dihasilkan.

6. Besar persentase serat bambu pada campuran bata beton yang dihasilkan, semakin besar persentase serat bambu pada bata beton maka tampak permukaan semakin kasar.

\section{DAFTAR PUSTAKA}

Balai Penelitian Bahan Departemen Perindustrian. Petunjuk Teknis Proses Pembuatan Bata Beton.: Departemen Perindustrian. Jakarta

Balaguru, Perlimalsany N.P Shak, Surendra. 1992. Fiber Reinforced Cement Composite.: International Edition, Jakarta

Majalah Trubus. 1992. Jenis-jenis Bambu.: Trubus, Jakarta

Murdock, L.J. 1981. Bahan dan Praktek Beton.: Erlangga, Jakarta

Neolaka, Amos. 1996. Pengantar Penelitian Pendidikan.: Grafindo Utama, Jakarta

Penelitian Antara PT. Indocemen dan Departemen Pekerjaan Umum. 1984. Bahan-bahan yang Memakai Semen untuk Pemukiman.: Departemen Pekerjaan Umum, Jakarta

Randing. 1994. Perencanaan Campuran dan Pengendalian Mutu Beton.: Departemen Pekerjaan Umum, Bandung

Randing, Nurman. 1975. Batu Buatan yang Tidak Dibakar.: LPMB Departemen Pekerjaan Umum, Bandung

Supribadi, I.K. 1986. IImu Bahan Bangunan Gedung.: Amrico, Bandung

SIl 0285-84. 1984. Mutu dan Cara Uji Bata Beton Pejal.: Departemen Perindustrian, Jakarta

SII 0285-84. 1984. Mutu dan Cara Uji Bata Beton.: Departemen Perindustrian, Jakarta

SNI 08-1111-1989. 1989. Cara Uji Kehalusan Serat Batang.: Badan Standarisasi Nasional, Jakarta

SNI 03-1113-1989. 1989. Cara Uji Panjang Berkas Serat Batang.: Badan Standarisasi Nasional, Jakarta 
SNI 03-0348-1989. 1989. Mutu dan Cara Uji Bata Beton Pejal. Badan Standarisasi Nasional, Jakarta

Widianto, David. 1995. Sifat Mekanik Beton dengan Fiber Bambu.: Universitas Gajah Mada, Yogyakarta 